\title{
TWIN-ROLL CASTING OF MAGNESIUM WIRE: AN INNOVATIVE CONTINUOUS PRODUCTION ROUTE
}

\author{
Marie MOSES, Heike WEMME, Madlen ULLMANN, Rudolf KAWALLA, Ulrich PRAHL \\ TU Bergakademie Freiberg, Institute of Metal Forming, Freiberg, Germany, EU, office@imf.tu-freiberg.de
}

https://doi.org/10.37904/metal.2019.812

\begin{abstract}
Within the last year and for the first time worldwide, the innovative twin-roll casting process has been implemented for magnesium wire at the pilot plant at the Institute of Metal Forming of TU Bergakademie Freiberg. The aim of this study is to present a new process route via continuously twin-roll casting AZ31 magnesium alloy wires. Due to the combination of solidification and forming in one process step, in rolling direction deformed grains are present and precipitates are fine distributed. Remarkably, only a short heat treatment after twin-roll casting is necessary to dissolve segregations and to form equiaxed grains. Three states, namely twin-roll cast and two selected heat-treated, are characterized by means of microstructural investigations, texture investigations, tensile tests and hardness measurements.
\end{abstract}

Keywords: Twin-roll casting, magnesium, AZ31, wire

\section{INTRODUCTION}

Magnesium and its alloys have great lightweight construction potential due to their low density and specific high strength. By using them, fuel consumption of automobiles can be reduced in the future in order to moderate $\mathrm{CO}_{2}$ emissions [1]. Further fields of application are aerospace, (bio-) medical and sports industry [2]. In addition, the field of additive manufacturing as a future technology is very interesting for magnesium alloy thin wires. The use of magnesium alloy wires is necessary to join magnesium alloy components in the abovementioned branches of industry with the aid of welding and assembly techniques. Conventionally produced magnesium alloy wires are manufactured by casting and then extruded into thin wires in several extrusion operations with intermediate heating [3]. In order to produce magnesium wires with a diameter of less than $2 \mathrm{~mm}$, final wire drawing operations are carried out with intermediate heating [4]. The conventional production route for magnesium wires requires many process steps with intermediate heating and is limited in wire length. In contrast to that, twin-roll casting (TRC) is an energy- and cost-efficient production technology for magnesium semi-finished products due to the saving of process steps $[5,6]$. The combination of solidification and forming in one process step results in a reduction of segregations, improved homogeneity of the microstructure and a finer distribution of precipitates [7]. In order to manufacture a magnesium long product economically, the TRC technology, which was successfully tested for magnesium strips at the Institute of Metal Forming (IMF) at the TU Bergakademie Freiberg, was transferred to the production of wire (patent no. DE102012209568). For this purpose, a pilot plant for the production of TRC magnesium wires was put into operation by the end of 2017. In this article, the process of twin-roll casting magnesium wire is first explained. This is followed by a presentation and discussion of the results of the trials with regard to the geometry, the microstructure, the texture and the mechanical properties of the TRC wire including heat treatment.

\section{MATERIAL AND METHODOLOGY}

\subsection{Material and Twin-roll casting}

The chemical composition of the used magnesium alloy is shown in Table 1. In comparison to DIN EN 12438, it is noticeable that the aluminium content is significantly lower than prescribed (2.5-3.5 wt\%). Zinc and manganese contents are in the standard. The process of twin-roll casting is characterized by the fact that the 
solidification and forming of the material take place in one process step. The principle is shown schematically in Figure 1 [8]. First, the melt heated in the melting furnace is transferred via a heated casting nozzle into the roll gap between two water-cooled rolls. The rolls have a circumferential, closed oval groove. On contact with the rolls, the melt (marked red) immediately begins to solidify in the groove. The orange marked zone shows the partly solidified melt. Before the narrowest point between the rolls, a through-solidified metal (marked yellow) is present, which is then rolled to form a deformed structure. In the trial, a casting speed of $3.5 \mathrm{~m} / \mathrm{min}$ was set. The magnesium alloy melt was heated up to $710^{\circ} \mathrm{C}$ and transferred into the roll.

Table 1 Chemical composition of the used magnesium alloy in (wt\%)

\begin{tabular}{|l|l|l|l|l|}
\hline Element & Al & Zn & Mn & Mg \\
\hline Average & 2.2 & 1.0 & 0.3 & 96.5 \\
\hline
\end{tabular}



Figure 1 Schematic principle of the TRC process after [8]

\subsection{Methodology of material analysis}

The twin-roll cast magnesium wire was cut into slices and were cold embedded in the longitudinal and transverse sections. After several grinding steps, the samples were polished by using OPS for $90 \mathrm{~s}, 40 \mathrm{~N}$ and $150 \mathrm{rpm}$. The etching was carried out with picric acid $(70 \mathrm{ml}$ alcohol, $10 \mathrm{ml}$ water, $10 \mathrm{ml}$ acetic acid, and $4.2 \mathrm{~g}$ picric acid). Optical micrographs were taken. Additionally, the samples were investigated by using energy dispersive X-ray spectroscopy (EDX analysis) and electron backscatter diffraction (EBSD) at the scanning electron microscopy (SEM) Jeol JSM 7800 F. Previously, ion polishing was carried out. After twin-roll casting, some samples were heat-treated in an air radiation furnace for different durations $(5 \mathrm{~min}, 15 \mathrm{~min}, 30 \mathrm{~min}, 1 \mathrm{~h}$ and $3 \mathrm{~h}$ ) and temperatures $\left(400{ }^{\circ} \mathrm{C}, 430^{\circ} \mathrm{C}, 460^{\circ} \mathrm{C}, 490^{\circ} \mathrm{C}\right.$ and $\left.520^{\circ} \mathrm{C}\right)$. The aim of the heat treatment was to homogenize the material, to get an equiaxed structure and to dissolve segregations. The specimens $460{ }^{\circ} \mathrm{C} / 15 \mathrm{~min}$ and $520^{\circ} \mathrm{C} / 5$ min were chosen for further investigations. Hardness measurements were carried out both at the edge and in the middle of the specimen using the Vickers hardness test method (HV10). Quasistatic tensile tests were performed at room temperature. The geometry of the tensile specimens corresponds to DIN 50125 shape B.

\section{RESULTS AND DISCUSSION}

\subsection{Twin-roll cast state}

An oval magnesium alloy wire measuring $20.0 \mathrm{~mm} \times 9.2 \mathrm{~mm}$ is produced (see Figure 2a)). Excess melt solidifies as a burr between upper and lower roll. Interestingly, the surface of the wire exhibits occasionally fine cracks, which were detected by a dye penetration test. No release agent was used. Therefore, it can be assumed that a water-graphite lubrication can prevent those fine surface cracks in future. The microstructure of the wire in the longitudinal section is shown in Figure $\mathbf{2 b}$ ). The solidification of the melt begins at the cooled 
rolls, which causes fine rapidly solidified grains at the edge. Finally, the upper and lower solidification front meet and the residual melt forms a central segregation. Some of the grains are stretched in the forming direction. Between the grains, there are segregation phases and scattered round precipitates in the grains and at the grain boundaries (see Figure $2 \mathrm{c}$ )). The lower half of the wire has a finer microstructure. Presumably, the melt flow was influenced by a melt surge at the start of casting in such a way that different flow velocities prevailed over the entire cross-section. As a result, the lower and upper sides of the wire solidified at different speeds. This also can be seen by the shifted central segregation.
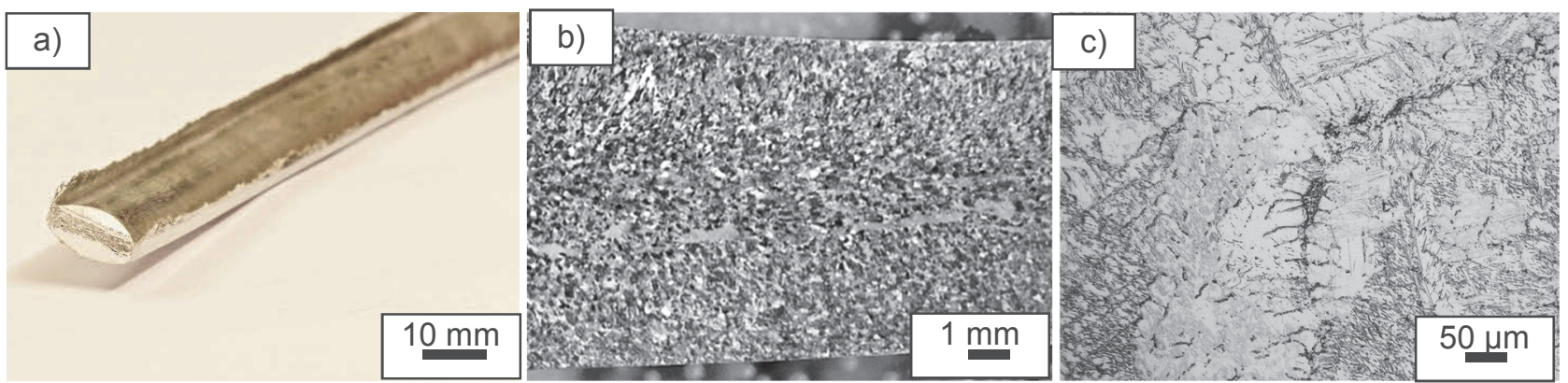

Figure 2 TRC wire cut in profile a), microstructure of the TRC wire in longitudinal section b) and microstructure of the TRC wire in cross section c)

In the SEM, the microstructure was examined more closely using EDX. The small round precipitates contain aluminium and manganese and are probably $\mathrm{Al}_{8} \mathrm{Mn}_{5}$ particles as described in [8-10]. A few fine precipitates were found at the grain boundaries, which were difficult to image due to their small size. These could be the intermetallic phases named in [8] Y $\left(\mathrm{Mg}_{17}(\mathrm{Al}, \mathrm{Zn})_{12}\right)$ and $\rho\left(\mathrm{Al}_{2} \mathrm{Mg}_{5} \mathrm{Zn}_{2}\right)$.

In the EBSD investigations, two areas were selected, one with more globular grains (see Figures 3 a) - d)) and one with more grains stretched in the rolling direction (see Figures $3 \mathbf{e}$ ) - h). In the figure, 001 corresponds to the plane normal of the longitudinal sample and 010 to the rolling direction.
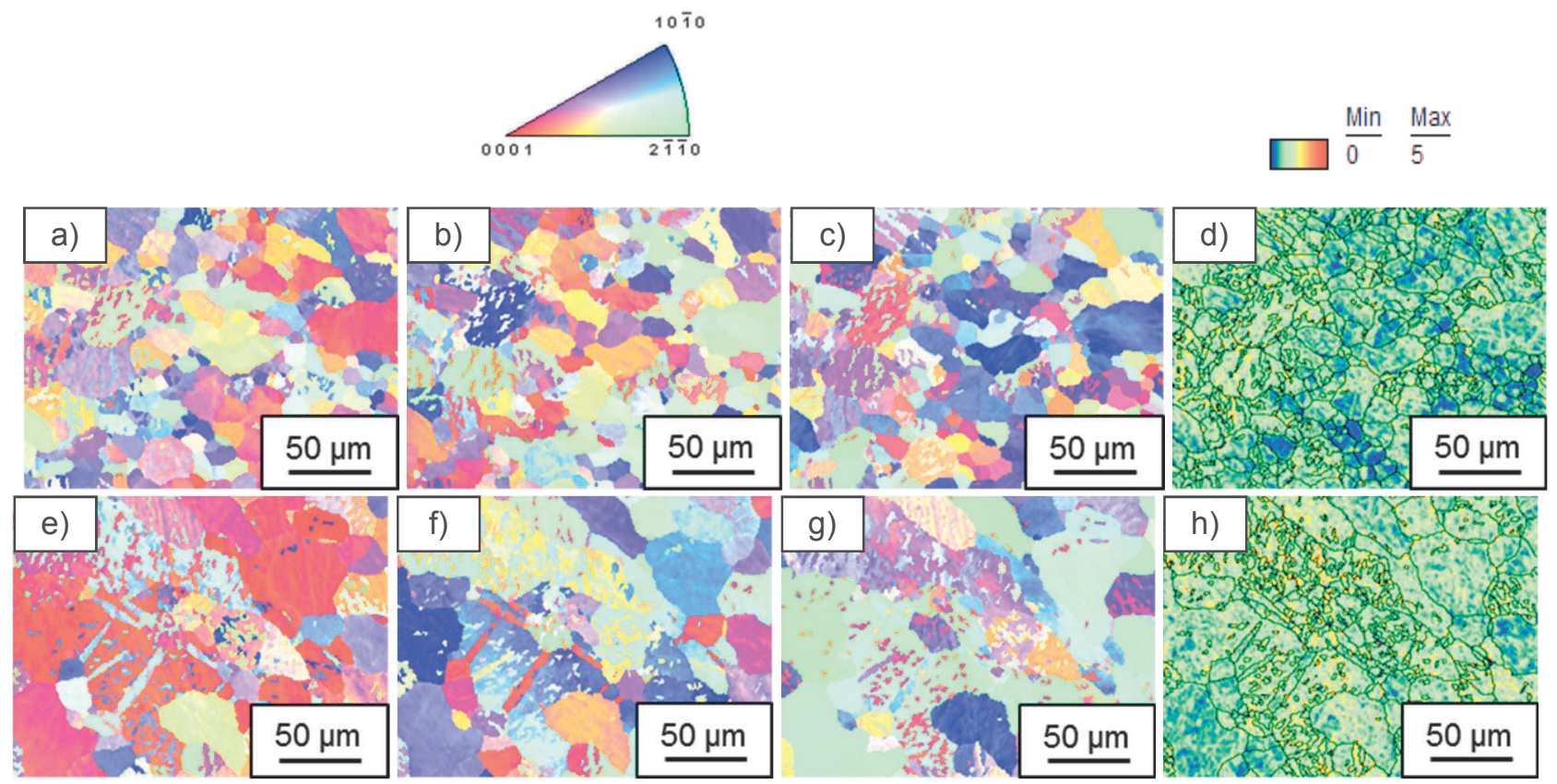

Figure 3 EBSD Measurements of TRC sample: a) 100, b) 010, c) 001 orientation and d) misorientation map of more globular grain area, e) 100, f) 010, g) 001 orientation and h) misorientation map of area with more stretched grains 
The globular grains show no texture, whereas the grains stretched in the rolling direction predominantly show a basal texture as well as twins. The reason for this is their stronger deformation by the rolls, which is also shown in the misorientation mappings (see Figures $\mathbf{3} \mathbf{d}$ ) and $\mathbf{h}$ )). Here areas with little orientation differences of crystallites with their neighbours are shown in blue (almost $0^{\circ}$ ). More strongly deformed areas are shown in green to yellow. The most strongly deformed areas are red ( $5^{\circ}$ and more).

As shown in Table 2, the wire has a moderate strength and elongation at fracture. The various areas in the microstructure are reflected in the hardness measurements of the twin-roll cast wire. It can be seen that the lower edge has $25 \%$ higher hardness values. The increased grain boundaries in the fine microstructure contribute to the hardening.

Table 2 Mechanical properties of twin-roll cast state

\begin{tabular}{|c|c|c|c|c|c|}
\hline $\begin{array}{c}\mathbf{0} .2 \% \text { Yield } \\
\text { strength } \\
\text { (MPa) }\end{array}$ & $\begin{array}{c}\text { Tensile } \\
\text { strength (MPa) }\end{array}$ & $\begin{array}{c}\text { Elongation at } \\
\text { fracture } \\
\text { (\%) }\end{array}$ & $\begin{array}{c}\text { Vickers } \\
\text { hardness HV10 } \\
\text { (middle) }\end{array}$ & $\begin{array}{c}\text { Vickers } \\
\text { hardness HV10 } \\
\text { (upper edge) }\end{array}$ & $\begin{array}{c}\text { Vickers } \\
\text { hardness HV10 } \\
\text { (lower edge) }\end{array}$ \\
\hline $118 \pm 2$ & $225 \pm 4$ & $10.0 \pm 0.2$ & $48.9 \pm 2$ & $52.2 \pm 1.1$ & $63.8 \pm 2.1$ \\
\hline
\end{tabular}

\subsection{Heat-treated state}

Heat treatment serves to homogenize the microstructure, i.e. segregations are to be dissolved and the cast microstructure is to be converted into globular, low-dislocation grains. In order to produce an easily deformable, ductile material e.g. for further forming steps, sufficiently high annealing temperatures and times were required. Table 3 shows the selected parameters and the evaluation of the heat treatment experiments. At a temperature of $400{ }^{\circ} \mathrm{C}$, the twin-roll cast microstructure begins to transform into a globular microstructure, but an annealing time of more than 1 hour is required to complete this process. At $400{ }^{\circ} \mathrm{C}$ and $30 \mathrm{~min}$, the first new grain formation was occasionally detected by optical micrographs. However, the adjustment to a globular structure has not been completed so far.

Table 3 Evaluation of heat treatment experiments on TRC wire using light microscopic examination

\begin{tabular}{|c|c|c|c|c|c|}
\hline & $5 \mathrm{~min}$ & $15 \mathrm{~min}$ & $30 \mathrm{~min}$ & $1 \mathrm{~h}$ & $3 \mathrm{~h}$ \\
\hline $400^{\circ} \mathrm{C}$ & $x$ & $x$ & $\begin{array}{c}\text { Start of grain } \\
\text { transformation }\end{array}$ & $\begin{array}{c}\text { Grain } \\
\text { transformation }\end{array}$ & Globular grains \\
\hline $430^{\circ} \mathrm{C}$ & $\mathrm{x}$ & $x$ & Globular grains & $x$ & $x$ \\
\hline $460{ }^{\circ} \mathrm{C}$ & $x$ & $\begin{array}{c}\text { Globular grains, } \\
\text { segregations } \\
\text { dissolved }\end{array}$ & $\begin{array}{c}\text { Globular grains, } \\
\text { segregations } \\
\text { dissolved }\end{array}$ & $x$ & $x$ \\
\hline $490{ }^{\circ} \mathrm{C}$ & $x$ & $\begin{array}{c}\text { Globular grains, } \\
\text { segregations } \\
\text { dissolved }\end{array}$ & $\begin{array}{c}\text { Globular grains, } \\
\text { segregations } \\
\text { dissolved }\end{array}$ & $x$ & $x$ \\
\hline $520^{\circ} \mathrm{C}$ & $\begin{array}{c}\text { Globular grains, } \\
\text { segregations } \\
\text { dissolved }\end{array}$ & $x$ & $x$ & $x$ & $x$ \\
\hline
\end{tabular}

The second goal of the heat treatment, the dissolution of fine segregations from the twin-roll casting process (see Figure $2 \mathrm{c}$ )), was achieved at a temperature of $460{ }^{\circ} \mathrm{C}$ and higher (see Figure 4). Only particularly large segregations of a few micrometre cannot be dissolved even at high temperatures. Thus, it is to be expected that apart from non-dissolvable particles and larger segregations at $460{ }^{\circ} \mathrm{C}$ a matrix with homogeneous chemical composition and globular grains is present. The sample $460^{\circ} \mathrm{C} / 15 \mathrm{~min}$ shows an average grain size of $23.8 \mu \mathrm{m}$, while the sample $520^{\circ} \mathrm{C} / 5$ min shows a slightly stronger grain growth with an average grain size of $28.8 \mu \mathrm{m}$ after static recrystallization. 

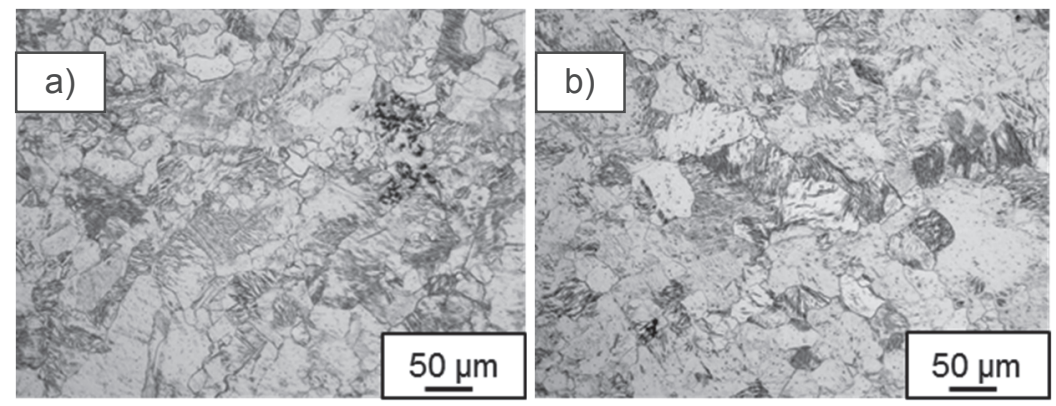

Figure 4 Microstructure of selected heat treated states: a) $460{ }^{\circ} \mathrm{C} / 15 \mathrm{~min}$ and b) $520{ }^{\circ} \mathrm{C} / 5 \mathrm{~min}$

SEM images in Figure 5 reveal large differences in the precipitation behaviour of the two selected heat treatments. In the $460^{\circ} \mathrm{C}$ sample, more fine precipitates were formed at the grain boundaries compared to the twin-roll cast material. The precipitates are too fine to be analysed by EDX. However, if the alloy content of the matrix is measured and compared with the TRC state, aluminium and zinc precipitate presumably in the compound $\mathrm{Mg}_{17}(\mathrm{Al}, \mathrm{Zn})_{12}$. The coarser particles are still the Al-Mn compound known from the TRC state.
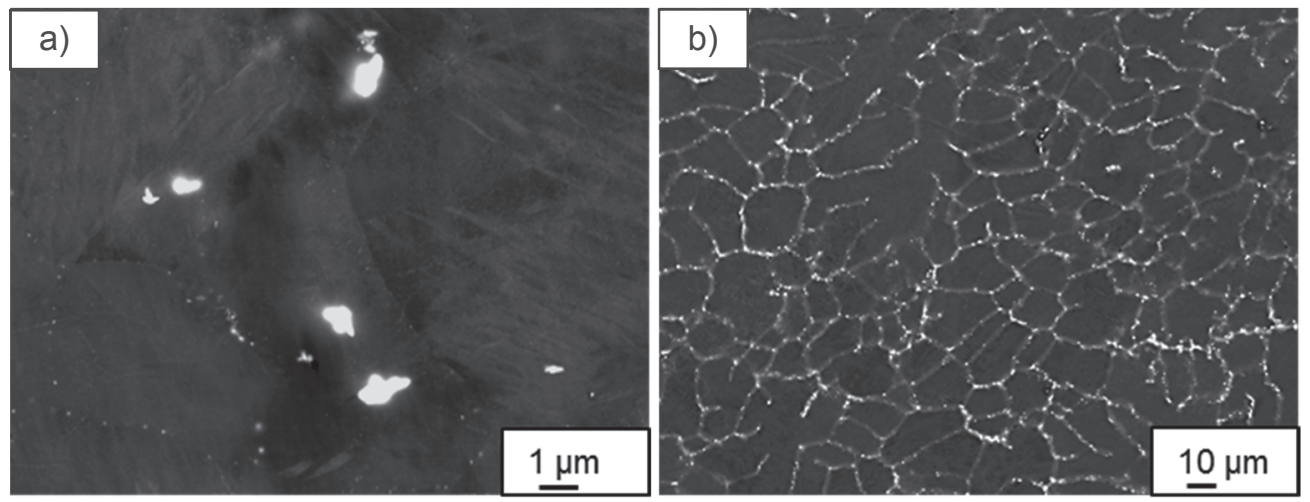

Figure 5 SEM images of selected heat treated states: a) $460{ }^{\circ} \mathrm{C} / 15 \mathrm{~min}$ and b) $520{ }^{\circ} \mathrm{C} / 5 \mathrm{~min}$

At $520^{\circ} \mathrm{C}$, longer time while cooling was left to precipitate aluminium and zinc, forming a kind of network of precipitation phases along the grain boundaries. Here the particles are so coarse that they can be clearly identified with EDX as (Mg-)Al-Zn compounds. After heat treatment, no significant changes in the distinctive basal texture are identified.

In contrast to that, significant changes in the mechanical properties are detected (see Table 4).

Table 4 Mechanical properties heat-treated state

\begin{tabular}{|c|c|c|c|c|c|}
\hline Heat treatment & $\begin{array}{c}\mathbf{0 . 2} \% \text { Yield } \\
\text { strength } \\
\text { (MPa) }\end{array}$ & $\begin{array}{c}\text { Tensile strength } \\
\text { (MPa) }\end{array}$ & $\begin{array}{c}\text { Elongation at } \\
\text { fracture } \\
\text { (\%) }\end{array}$ & $\begin{array}{c}\text { Vickers } \\
\text { hardness HV10 } \\
\text { (middle) }\end{array}$ & $\begin{array}{c}\text { Vickers } \\
\text { hardness HV10 } \\
\text { (edge) }\end{array}$ \\
\hline $460^{\circ} \mathrm{C} / 15 \mathrm{~min}$ & $115 \pm 3$ & $238 \pm 3$ & $18.3 \pm 0.2$ & $52.4 \pm 1.4$ & $51.9 \pm 1.1$ \\
\hline $520^{\circ} \mathrm{C} / 5 \mathrm{~min}$ & $93 \pm 3$ & $210 \pm 3$ & $10.8 \pm 0.7$ & $50.0 \pm 1.3$ & $49.6 \pm 1.3$ \\
\hline
\end{tabular}

The sample $460{ }^{\circ} \mathrm{C} / 15$ min shows an increase in elongation at fracture of almost $100 \%$ as well as an increase in tensile strength. This can be explained on one hand by the transformation of the grain structure into globular, nearly dislocation-free grains and on the other hand by the fine precipitation of the alloying elements. Fine precipitates can contribute to increased strength without significantly reducing elongation at break. However, at a higher heat treatment temperature of $520^{\circ} \mathrm{C}$, the precipitates are too coarse so that they no longer increase the strength. They also have a negative effect on elongation at fracture as they hinder grain boundary 
sliding and the material tends to brittle. A homogenization of the hardness through the homogenization of the microstructure was achieved.

\section{CONCLUSION}

The cost- and resource-efficient production of magnesium wires by twin-roll casting was shown. In order to achieve good mechanical properties and a homogeneous microstructure, a subsequent heat treatment after twin-roll casting is necessary. In order to guarantee the homogeneity of the microstructure and a fine distribution of the alloying elements, a short heat treatment at $460{ }^{\circ} \mathrm{C}$ for $15 \mathrm{~min}$ is suitable. However, higher temperatures lead to coarsening of the precipitates with the consequence of low elongation at fracture.

\section{ACKNOWLEDGEMENTS}

The authors thank the Saxon Ministry of Science and Arts for the financial support of the pilot plant through the European funds for regional development. We also acknowledge the financial funding of the project No. 100270111 through the European social funds.

Further, we would like to thank Mr. Lachmann for his support in the SEM examinations.

\section{REFERENCES}

[1] MORDIKE, B. L. and EBERT, T. Magnesium: Properties - applications - potential. Materials Science and Engineering A. 2001. vol. 302, pp. 37-45.

[2] NEH, K., ULLMANN, M., OSWALD, M., BERGE, F. and KAWALLA, R. Twin roll casting and strip rolling of several magnesium alloys. Materials Today: Proceedings. 2015. vol. 2, pp. S45-S52.

[3] MUELLER, K. B. Direct and Indirect Extrusion of AZ31. Magnesium technology. 2002. pp. 187-192.

[4] BAJOR, T., MUSKALSKI, Z. and SULIGA, M. Research on the drawing process with large total deformation wires of AZ31 alloy. Journal of Physics: Conference Series. 2010. vol. 240, no. 1, pp. 1-4.

[5] PARK, S.S., BAE, G. T., KANG, D. H., JUNG, I.-H., SHIN, K. S. and KIM, N. J. Microstructure and tensile properties of twin-roll cast Mg-Zn-Mn-Al alloys. Scripta Materialia. 2007. vol. 57, no. 9, pp. 793-796.

[6] DI, H.-S., WANG, G.-S., HUANG, F. and GUO, X.-H. AZ31B magnesium sheet manufactured by twin roll strip casting process. In $9^{\text {th }}$ International Conference on Technology of Plasticity. Gyeongju, South Korea: ICTP 2008, 2008, pp. 1286-1291.

[7] WANG, Y., KANG, S. B. and CHO, J. Microstructure and mechanical properties of Mg-Al-Mn-Ca alloy sheet produced by twin roll casting and sequential warm rolling. Journal of Alloys and Compounds. 2011. vol. 509, no. 3, pp. 704-711.

[8] WEMME, H., MOSES, M., OSWALD, M., ULLMANN, M., KAWALLA, R. and PRAHL, U. Anwendung des innovativen Gießwalzverfahrens zur wirtschaftlichen Herstellung von Magnesium-Langprodukten. In 10. Ranshofener Leichtmetalltage: Hochleistungsmetalle und Prozesse für den Leichtbau der Zukunft. Linz, Austria: LKR-Verlag, 2018, pp. 113-123.

[9] LASER, T., NÜRNBERG, M. R., JANZ, A., HARTIG, C., LETZIG, D., SCHMID-FETZER, R. and BORMANN, R. The influence of manganese on the microstructure and mechanical properties of AZ31 gravity die cast alloys. Acta Materialia. 2006. vol. 54, pp. 3033-3041.

[10] BRASZCZYNSKA-MALIK, K. N. Discontinuous and continuous precipitation in magnesium-aluminium type alloy Journal of Alloys and Compounds. 2009. vol. 477, no. 1-2, pp. 870-876. 